\title{
TANTANGAN PROGRAM STUDI BERBASIS ISLAM
}

\author{
Sholeh Fikri \\ IAIN Padangsidimpuan \\ sholehfikri@gmail.com
}

\begin{abstract}
The scarcity of enthusiasts for some Islamic-based study programs is one of the challenges faced at this time, therefore the study programs are trying hard to change the situation. The method used in this study is qualitative with a descriptive approach. By this this study, it is known that a scarcity study program should improve their elements such as management, administration, leadership, learning process, technical socialization and promotion as well as preparing alumni who are ready to use the community well.
\end{abstract}

Keywords: Scarcity, Islamic Based Study Programs, and Challenges.

\begin{abstract}
Abstrak
Kelangkaan peminat bagi sebagian program studi berbasis Islam merupakan salah satu tantangan yang dihadapi pada saat ini, oleh karenanya prodi-prodi tersebut berusaha keras untuk merubah situasi tersebut. Metode yang digunakan dalam kajian ini adalah kualitatif dengan pendekatan deskriptif. Dari hasil penelitian diketahui bahwa prodi yang langka peminat hendaknya memperbaiki elemen-elemen seperti manajemen, administrasi, kepemimpinan, proses pembelajaran, teknis sosialisasi dan promosi serta mempersiapkan alumni yang siap pakai sehingga mendapatkan perhatian dari masyarakat secara baik.
\end{abstract}

Kata Kunci: kelangkaan, program studi berbasisikan Islam, dan tantangan.

\section{PENDAHULUAN}

Berkembangnya dunia pendidikan menyebabkan persaingan yang makin ketat antar Perguruan Tinggi (PT) di Indonesia yang antara lain disebabkan oleh dampak globalisasi serta makin banyaknya perguruan tinggi di Indonesia, sementara jumlah minat masuk para siswa tamatan Sekolah Menengah ke perguruan tinggi justru makin kecil karena pertimbangan ekonomis maupun sisi kepraktisan. Berdasarkan kondisi tersebut, terdapat beberapa masalah utama yang dihadapi oleh hampir seluruh pendidikan tinggi di Indonesia.

Upaya perguruan tinggi, dalam meningkatkan manajemen merupakan salah satu tuntutan yang tidak dapat terelakkan. Karena itu, manajemen perguruan tinggi harus segera mencari jalan tengah untuk membingkai pengelolaan ya secara elegan dan menyejukkan. Apapun yang akan dilakukan oleh pihak perguruan tinggi merupakan tuntutan 
382 | TAZKIR: Jurnal Penelitian Ilmu-ilmu Sosial dan Keislaman

Vol. 04 No. 2 Desember 2018

masyarakat dan sekaligus untuk memenuhi kebutuhan dan tantangan global. Sehingga menajemen merupakan jantung dari dunia pendidikan tinggi yang akan memberikan atmosfir bagi pemenuhan kebutuhan pasar, serta mampu menciptakan lapangan kerja.

Perguruan Tinggi di Indonesia, saat ini dan yang akan datang, menghadapi permasalahan rendahn ya tingkat kelayakan strategis yang bersumber dari adanya kesenjangan antara tuntutan lingkungan dan persaingan dengan sumber daya internalnya. Daya saing sejumlah Perguruan Tinggi di Indonesia dalam persaingan Pendidikan Tinggi cenderung menurun sehingga mengancam keunggulan posisi dan keberlanjutan Perguruan Tinggi yang bersangkutan.

Fenomena masalah di atas dihadapi oleh Perguruan Tinggi manapun, tidak terkecuali Perguruan Tinggi Agama Islam (PTAI), yang merupakan bagian integral dalam sistem pendidikan tinggi di Indonesia. Permasalahan tersebut dapat dipecahkan dengan cara melakukan perbaikan secara berkelanjutan terhadap mutu sosialisasi, rekrutmen mahasiswa, sumber daya manusia, proses, dan fasilitas fisik.

Perguruan Tinggi Islam Negeri menghadapi berbagai tantangan, di antaranya kurangn ya dana dari pemerintah, kebutuhan akan pengembangan program studi yang relevan dengan kebutuhan masyarakat, dan tuntutan akan efisiensi dan efektifitas di PTAI termasuk di dalamnya tidak seimbangnya kuota yang disediakan dengan peminat yang mendaftar, kuota yang disediakan besar sedangkan peminatnya sedikit menjadikan pendapatan sedikit dan kecil pula untuk memenuhi kegiatan-kegiatan yang akan menunjang skill dan kompetensi seluruh civitas akademika adalah beberapa tantangan yang harus dihadapi juga oleh IAIN Padangsidimpuan. Hal ini menuntut IAIN Padangsidimpuan untuk lebih giat dalam menyusun strategi pengembangan agar dapat menjawab tantangantantangan di atas.

Perguruan tinggi dituntut untuk selalu memperhatikan secara terus menerus peningkatkan mutu pendidikan. Ada banyak faktor mengapa perguruan tinggi harus benar-benar memperhatikan mutu pendidikan. Secara garis besar faktor-faktor tersebut dapat dibagi menjadi dua yaitu faktor-faktor yang berasal dari luar (external forces) dan faktor-faktor yang berasal dari dalam (internal driven) institusi pendidikan tinggi. Globalisasi dan 
liberalisasi merupakan dua faktor utama yang mengharuskan institusi Pendidikan Tinggi melakukan antisipasi dan adaptasi dan jika perlu melakukan perubahan untuk dapat memenuhi keinginan dan kebutuhan stakeholders $^{1}$. Sedangkan dari faktor internal antara lain berkurangn ya subsidi untuk pendidikan tinggi akibat kecilnya anggaran negara untuk sektor pendidikan, persaingan untuk mendapatkan mahasiswa, permintaan, akuntabilitas dan produktivitas perguruan tinggi oleh stakeholders.

Secara umum, lembaga pendidikan Islam masih tertinggal. Kita harus menerima kenyataan yang pahit bahwa posisi pendidikan Islam di Indonesia menempati "kelas ekonomi" walau tetap memiliki komitmen untuk menjadikannya sebagai bahan pertimbangan dalam membangun kembali di masa mendatang. Hal ini menuntut para pemimpin lembaga pendidikan Islam mampu membaca selera masyarakat. Para pemimpin atau pengelola lembaga pendidikan Islam dituntut memiliki orientasi yang jelas dan melakukan pembenahan- pembenahan melalui strategi-strategi baru untuk meningkatkan kemajuan sehingga menjadi lembaga pendidikan Islam yang menjanjikan masa depan, baik jaminan keilmuan, kepribadian, maupun ketrampilan.

Permasalahan mutu di dalam lembaga pendidikan Islam merupakan permasalahan yang paling serius dan paling kompleks. Rata-rata lembaga pendidikan Islam belum ada yang berhasil merealisasikan mutu pendidikannya. Padahal mutu pendidikan itu menjadi cita-cita bersama seluruh pemikir dan praktisi pendidikan Islam, bahkan telah diupayakan melalui berbagai cara, metode, pendekatan, strategi dan kebijakan². Sejak beberapa tahun terakhir muncul kecenderungan jumlah mahasiswa atau peminat Program Studi (Prodi) tertentu di Perguruan Tinggi Agama Islam Negeri dan juga di IAIN Padangsidimpuan mengalami kelangkaan peminat dari tahun ke tahun. Program Studi yang mengalami kelangkaan peminat itu terjadi di Fakultas Dakwah dan Ilmu Komunikasi (FDIK). Ada beberapa faktor mengapa Prodi-prodi tersebut tidak atau kurang menarik bagi calon mahasiswa di IAIN Padangsidimpuan.

${ }^{1}$ Azyumardi Azra. IAIN di Tengah Paradgma Baru Perguruan Tinggi. Tersedia di http://www.diktis.net/artikel/azyu01.asp, di akses pada 05 Maret 2018.

2 Qomar Mujamil. Manajemen Pendidikan Islam: Strategi Baru Pengelolaan Lembaga Pendidikan Islam (Jakarta: Erlangga, 2007), hlm.105 
384 | TAZKIR: Jurnal Penelitian Ilmu-ilmu Sosial dan Keislaman

Vol. 04 No. 2 Desember 2018

Pertama, ada anggapan bahwa masa depan lulusan fakultas/jurusan/prodi tersebut tidak jelas berkaitan dengan lapangan pekerjaan atau bidang kerja yang tersedia di masyarakat. Persepsi ini muncul karena selama ini lulusan FDIK hanya mengisi peluang bidang pekerjaan yang berkaitan dengan agama saja, seperti bidang dakwah, pendidikan, aktif di lembaga keagamaan, atau berkiprah di birokrasi keagamaan (Kementrian Agama). Ketika bidang pekerjaan pada sektor modern semakin berkembang dan diverisifikatif, alumni FDIK tidak mampu mengisinya.

Kedua, berkurangn ya minat masyarakat Muslim (sebagai pendukung PTAI) mengirimkan anak-anaknya untuk mendalami ilmu-ilmu agama "tradisional-murni" ke IAIN Padangsidimpuan. Kondisi ini dipicu mungkin karena ada perubahan mindset atau bahkan paradigma tentang "belajar agama" yang tidak mesti dan melulu melalui lembaga pendidikan Islam semacam pesantren atau perguruan tinggi Islam. Di sisi lain, status Akreditasi Prodi menjadi tolak ukur penilaian pilihan. Kondisi ini berkaitan dengan semakin banyaknya pilihan bagi orang tua Muslim untuk memilih perguruan tinggi mana yang cocok dan lebih menjanjikan masa depan bagi anak- anaknya.

Ketiga, persaingan antar perguruan tinggi semakin ketat dan kompetitif. Masing-masing perguruan tinggi berupaya menarik calon mahasiswa sedemikian rupa sehingga calon mahasiswa mempunyai pilihan bebas untuk menentukan perguruan tinggi mana yang akan dipilih. Pada saat yang sama, penjaringan calon pegawai negeri sipil menjadi acuan untuk memilih jurusan.

Keempat, sebagian pengelola/pimpinan di IAIN Padangsidimpuan kurang memberikan perhatian sewajarn ya terhadap fakultas/jurusan/prodi yang mengalami kejenuhan atau kurang peminat dengan tawaran program yang lebih menarik, sarana prasarana, kreatifitas yang menjanjikan. Kebanyakan calon mahasiswa lebih tertarik pada jurusan/fakultas Tarbiyah dan Fakultas Ekonomi dan Bisnis Islam (FEBI), sementara beberapa jurusan lain mengalami penurunan peminat.

Berdasarkan rumusan misi, tujuan dan visi ke masa depan itu, di IAIN Padangsidimpuan perlu dilakukan pembenahan-pembenahan terhadap kurikulum, dosen, proses belajar mengajar, fasilitas belajar, manajemen pendidikan dan lingkungan belajar. Usaha meningkatkan mutu pendidikan Islam juga dipengaruhi oleh kualitas input mahasiswa. Ini 
adalah faktor yang amat penting karena kualitas mahasiswalah yang menjadi ukuran bagi suatu lembaga pendidikan. Lulusan yang baik menunjukkan bahwa proses pendidikan di lembaga tersebut baik, begitu pula sebaliknya. Ini dapat dilakukan dengan melakukan saringan masuk yang standar dan ketat. Namun, yang dihadapi saat ini adalah kenyataan bahwa calon yang berminat masuk ke Program Studi Manajemen Dakwah (MD) dan Pengembangan Masyarakat Islam (PMI) adalah lulusan SLTA/SMK/MAN yang bukan siswa berprestasi (siswa berprestasi lebih memilih perguruan tinggi lain yang lebih menjanjikan masa depan yang lebih cerah). Dengan kenyataan seperti ini, yang bisa kita usahakan hanyalah melakukan pembinaan pada SDM yang kurang berprestasi itu sehingga dapat keluar dengan kemampuan yang mendekati standar yang telah ditetapkan.

Untuk faktor eksternal dapat disebutkan antara lain: 1) bergesernya aspirasi pendidikan masyarakat (Umat Islam) yang dulu lebih mementingkan pendidikan agama ke ilmu umum seiring dengan laju pembangunan bangsa; 2) semakin sempitnya peluang lulusan FDIK IAIN Padangsidimpuan untuk bekerja sebagai pegawai negeri sebagai akibat zero growth (atau bahkan minus growth) pemerintah di bidang kepegawaian. Sementara itu, pekerjaan di sektor swasta tidak memberikan imbalan yang cukup menarik bagi lulusan FDIK IAIN Padangsidimpuan; 3) Prodi MD dan PMI dianggap sebagai prodi yang tidak menjanjikan prospek masa depan cerah. 4) beratnya tantangan yang harus dihadapi oleh ahli agama dalam profesinya mungkin juga membuat sebagian calon mahasiswa kurang berminat untuk menjadi ahli agama; 5) kurangn ya minat lulusan SLTA sederajat yang memiliki potensi akademik terpuji untuk belajar di IAIN Padangsidimpuan menyebabkan mutu kebanyakan mahasiswa IAIN Padangsidimpuan menjadi kurang ideal.

Untuk faktor internal dapat disebutkan, antara lain: 1) kurangnya sarana pendukung untuk pengembangan prodi; 2) kurikulum: kelemahan utama kurikulum berlaku (KKNI) yang digunakan saat ini adalah kurangnya pemahaman mendalam oleh pihak pendidik, untuk mencapai tuntutan kurikulum tersebut; 3) dosen: kurangnya dosen berpendidikan linear sebagai tenaga pengajar di Prodi MD dan PMI. 4) proses belajar mengajar: proses belajar mengajar yang dilaksanakan pada Prodi MD dan PMI 
386 | TAZKIR: Jurnal Penelitian Ilmu-ilmu Sosial dan Keislaman

Vol. 04 No. 2 Desember 2018

kebanyakan masih bersifat tradisional dan formalistis. Hal ini adalah akibat kurang jelas komunikatifnya kurikulum di FDIK saat ini sehingga arah pendidikan kurang dipahami oleh pelaksana pendidik di lapangan; 5) input mahasiswa: sebagai akibat kurangn ya minat lulusan SLTA yang berkualitas masuk di IAIN Padangsidimpuan maka mutu input mahasiswa IAIN Padangsidimpuan menjadi kurang bagus; 6) fasilitas belajar: fasilitas belajar ini sangat minim berupa sarana ruang perkuliahan (wifi, infocus) dan sarana operasional perkantoran yang belum lengkap. Pembangunan fisik yang dibiayai pemerintah tampaknya belum menyentuh fasilitas belajar seperti laboratorium masing-masing prodi, Stasiun Pratikum Prodi, perpustakaan, dan sebagainya) kurang mendapatkan perhatian. Sampai saat ini pembangunan fisik lebih tampak daripada pembangunan laboratorium ataupun penyediaan buku perpustakaan yang lengkap; 7) Dana operasional. Dana operasional yang cukup diperlukan guna menjamin lancarnya kegiatan proses belajar mengajar guna menghasilkan lulusan yang bermutu dan berguna bagi masyarakat; 8) Rendahnya kemampuan dosen di IAIN Padangsidimpuan dalam melakukan publikasi ilmiah berskala Nasional dan Internasional. Kelemahan ini mengakibatkan rendahn ya informasi yang sampai kepada masyarakat tentang perkembangan ilmu yang diproduksi oleh perguruan tinggi. 9) Kurang terkaitnya kegiatan program pengabdian kepada masyarakat dengan hasil penelitian. Kebanyakan kegiatan program pengabdian kepada masyarakat yang dilakukan oleh FDIK digabungkan dengan kegiatan Kuliah Kerja Lapangan yang seringakali tidak merupakan penerapan hasil penelitian di bidang agama (Swara Ditpertais: No. 12 Th. II, 31 Juli 2004); 10) Promosi yang monoton dan belum proporsional, terlihat dari teknis yang berlaku dalam promosi masih berlaku sama dengan tahun-tahun sebelumnya serta cara yang ditempuh masih tetap sama antara prodi yang sudah ramai peminat dengan prodi yang langka peminat.

Kondisi standard jumlah mahasiswa setiap prodi adalah 1 dosen: 25 Mahasiswa $^{3}$. Jadi kalau jumlah dosen setiap Prodi minimal 6 (enam) orang dosen maka jumlah mahasiswa yang ideal itu adalah 6 x 25=150 orang Mahasiswa. Hasil studi awal didapatkan bahwa peminat mahasiswa yang masuk ke Prodi Manajemen Dakwah (MD) dan Prodi Pengembangan

${ }^{3}$ Fakultas Dakwah dan Ilmu Komunikasi, Renstra FDIK 2014-2022, hlm 22. 
Masyarakat Islam dari awal berdirinya pada tahun 2015 sampai saat ini. Prodi MD jumlah mahasiswanya sebanyak 50 orang dengan perincian sebagai berikut, smester VII $=9$ orang, smester $\mathrm{V}=6$ orang, smester $\mathrm{III}=10$ orang dan smester I=25 orang. Sedangkan Prodi Pengembangan Masyarakat Islam (PMI) jumlah mahasiswanya sebanyak 41 orang dengan perincian; semester $\mathrm{VII}=11$ orang, semester $\mathrm{V}=13$ orang, semester $\mathrm{III}=6$ dan semester $\mathrm{I}=11$ orang. ${ }^{4}$

Agar keberadaan Prodi yang langka peminat tersebut tetap mampu survive, maka tidak ada pilihan lain kecuali memicu dan memacu kualitas diri serta membuka diri terhadap trend global dunia pendidikan, tanpa harus kehilangan identitas. Konsekwensinya kebutuhan akan manajemen mutu (quality management) tidak dapat dihindari.

\section{METODE PENELITIAN}

Penelitian ini dilakukan dengan menggunakan pendekatan kualitatif dengan datanya didapat dari sumber primer dan sekunder. Data primer dari Ketua Prodi, Dekan, mahasiswa, dan stakeholder, sementara data sekunder diperoleh dari literatur. Teknik pengumpulan data melalui observasi dan wawancara, dan data dianalisis melalui reduksi data, deskripsi data, dan melakukan interpretasi untuk selanjutnya dilakukan pengecekan keabsahan data.

\section{KAJIAN TEORITIS}

\section{Dasar-dasar Pembukaan Program Studi (Prodi)}

Dalam rangka meningkatkan peran pendidikan tinggi di Indonesia dan memperkuat daya saing bangsa dalam menghadapi persaingan global, selain analisis lingkungan eksternal dan internal, Rencana Strategis Pendidikan Tinggi 2010-2014, dan PP No. 17 tahun 2010 tentang penyelenggaraan dan pengelolaan pendidikan juga bisa digunakan sebagai acuan untuk meningkatkan peran pendidikan tinggi di Indonesia dan memperkuat daya saing bangsa dalam menghadapi persaingan global. Secara makro perguruan tinggi akan menghadapi tantangan yang tidak ringan. Akibat percepatan arus perubahan sosial yang drastis, akhirnya secara sadar atau tidak,

${ }^{4}$ Sistem Informasi Akademik (SIAKAD) Fakultas Dakwah dan ilmu Komunikasi IAIN Padangsidimpuan, diakses 20 Desember 2017 
telah memaksa berbagai penjual jasa, termasuk perguruan tinggi untuk lebih adaptif terhadap perubahan tersebut. Untuk mengantisipasi perubahan yang dinamis itu, maka perguruan tinggi harus menyiapkan manajemen yang adaptif dan berorientasi pada kebutuhan customer. Perguruan tinggi (PT) dituntut memiliki visi, misi dan orientasi yang jelas, terbuka dan mempunyai tujuan jangka panjang yang dapat menciptakan produktifitas lulusan yang dapat diperhitungkan memperoleh out put yang dapat berdaya saing ditingkat nasional, serta mampu bersaing dengan lulusan dari pendidikan luar negeri.

Fakultas bisa memiliki beberapa program studi yang mengkaji satu jenis pendidikan khusus baik pendidikan akademik, pendidikan profesi atau pendidikan kejuruan. Program Studi adalah kesatuan kegiatan Pendidikan dan pembelajaran yang memiliki kurikulum dan metode pembelajaran tertentu dalam satu jenis pendidikan akademik, pendidikan profesi, dan/atau pendidikan vokasi ${ }^{5}$.

Pada dasarnya pembukaan program studi didasarkan pada pentingnya untuk memberi jawaban terhadap tuntutan jaman ke depan yang berlandaskan pada permintaan pasar kerja (market driven) dan atau hasil perenungan terhadap visi keilmuan (scientific vision). Permintaan pasar kerja (market driven) dan kondisi bursa lapangan kerja (market share) menjadi salah satu faktor penting yang harus mendapat prioritas pendirian Program Studi. ${ }^{6}$

Pembukaan program studi semestinya memperhatikan point-point yang menjadi ketentuan yang dijelaskan di atas, jika itu terjadi maka prodi tersebut akan menjadi prodi yang perfect di masa yang akan datang. Oleh karenanya sebelum prodi dibuka tentunya ada observasi awal agar dapat mengetahui kebutuhan dari stakeholder, hal inilah yang sering dilupakan oleh banyak perguruan tinggi. Beberapa pendapat hampir sama bahwa syaratsyarat yang harus dipenuhi dalam pembukaan program studi, dapat diterangkan sebagai berikut; pertama, pendekatan untuk mendirikan Program Studi harus berdasar visi keilmuan (scientific vision). Kedua, bahwa pendekatan untuk mendirikan Program Studi harus berdasar permintaan pasar

${ }^{5}$ Undang-Undang Republik Indonesia Nomor 12 Tahun 2012

${ }^{6}$ Nunun Tri Widarwati, Pengelolaan Program Studi, Jurnal Widyatama, No.2 / Volume 21 / 2012, hlm.116 
dan syarat ketiga adalah bahwa mendirikan Program Studi harus berdasar kombinasi dari keduanya7.

Pembentukan Program Studi berdasar scientific vision. Artinya bahwa program studi yang dibuka harus memiliki visi ke depan yang berbasis penelitian akademis secara ilmiah dan bisa dikembangkan secara terus menerus (continuous improvement) sesuai dengan kebutuhan dan perubahan jaman. Ini berarti bahwa Program Studi harus dibentuk melalui kajian mendalam berdasarkan visi keilmuan ke depan yang bermuara pada azas manfaat bagi kesejahteraan masyarakat. Bertolak dari hal tersebut, maka pendirian Program Studi berdasar (tuntutan dan permintaan pasar (market demand) yang lebih cenderung mempertimbangkan aspek kebutuhan pasar dalam kurun waktu yang relatif pendek, menengah dan panjang dengan basis pertimbangan pengembangan keilmuan.

Selanjutnya fakultas sebagai induk dari prodi-prodi yang ada yang bertanggung jawab secara struktural membina prodi dengan baik dan akan memperhatikan akreditasinya karena akreditasi merupakan barometer menentukan prodi itu kuat apa lemah. Nilai akreditasi menempati posisi penting dalam sebuah lembaga karena akreditasi merupakan pengakuan dan penilaian dari lembaga pemerintah yang terpercaya bahkan berikutnya nilai akreditasi prodi juga bisa menjadi daya tarik bagi mahasiswa untuk memilih prodi. Oleh karenanya pengelolaan secara baik menjadi indikator utama untuk mendapatkan nilai akreditasi yang memuaskan.

\section{Pengelolaan Program Studi Secara Profesional}

Mengelola prodi merupakan pekerjaan yang tidak ringan karena prodi yang menjadi nakoda dalam menentukan arah perjalanan untuk mengantar para penumpangnya mencapai pulau idaman, bahkan prodi memiliki dampak untuk menghasilkan tenaga-tenaga terampil dalam bidangnya. Memang satu prodi tidak akan muncul bisa maju secara tiba-tiba akan tetapi akan berjalan sesuai proses, dan prosesnya bisa cepat dan bisa lambat, karena yang menentukan kemajuannya adalah sumber daya manusia (SDM) yang menggerakkan prodi tersebut. Seperti yang disebutkan di atas sekali lagi jangan dilupakan di dalam proses tersebut ada orang-orang yang berjuang dengan penuh dedikasi untuk 
390 | TAZKIR: Jurnal Penelitian Ilmu-ilmu Sosial dan Keislaman

Vol. 04 No. 2 Desember 2018

memajukan lembaga pendidikan demi mempersiapkan generasi-generasi masa akan datang yang lebih baik.

Menurut Serian Wijatno beberapa masalah utama terjadi kelangkaan peminat bagi beberapa Prodi muncul antara lain persoalan manajemen, relevansi program pendidikan tinggi terhadap pasar kerja, perluasan daya tampung, dan pemerataan mutu pendidikan yang ditunjang dari aspek sarana dan prasarana, soft skill serta pelatihan keahlian. ${ }^{8}$

Selain dari aspek di atas kelangkaan peminat dipicu oleh rendahnya kualitas lulusan, penetapan kurikulum, kualitas dosen yang mengelola perkuliahan, fasilitas belajar, kualitas lingkungan belajar, kualitas manajemen dan kepemimpinan, dan kualitas input calon mahasiswa9. Secara teoritis pimpinan prodi menentukan arah yang akan dituju oleh prodinya yang berbentuk visi misi, selanjutnya hal yang tidak boleh dilupakan adalah tertib adminstrasi dari semua kegiatan yang dilakukan. Satu pendapat mengatakan, catatlah apa yang dilakukan dan lakukan apa yang sudah dicatat. adalah prinsip yang harus tetap dipegang

Sejak dari awal membuka prodi, pengelola prodi sudah menyiapkan halhal yang menjadi prasyarat yang sudah ditentukan oleh pemerintah dalam hal ini Menteri Agama dalam lingkungan KEMENAG dan keputusan Menteri Pendidikan dalam lingkungan Diknas.

Menurut SK MENDIKNAS Nomor 184/U/2001 ada beberapa dokumen yang harus dipersiapkan dalam pengembangan program, yaitu:

1. RIP Universitas

2. RENSTRA Universitas

3. Dokumen Hasil Studi Kelayakan

4. Draft Naskah Kurikulum Program Studi, yang didalamnya terdapat informasi tentang:

a. Tenaga

Kependidikan $b$.

Calon Mahasiswa

c. Sarana dan Prasarana

\footnotetext{
8Serian Wijatno, Pengelolaan Perguruan Tinggi Secara Efisien, Efektif, dan Ekonomis: Untuk Meningkatkan Mutu Penyelenggaraan Pendidikan Mutu Lulusan (Jakarta: Salemba Empat, 2009), hlm.37

9 Arief Furchan. Transformasi Pendidikan Islam di Indonesia (Yogyakarta: Gama Media, 2004), hlm.128
} 
d. Penyelenggaraan Pendidikan

e. Penyelenggaraan Penelitian

f. Penyelenggaraan Pengabdian kepada Masyarakat

g. Administrasi dan Pendanaan Program

Ketetapan dari Mendiknas di atas merupakan rambu-rambu yang harus dipatuhi dalam pengembangan Program studi, jurusan, fakultas maupun universitas. Dampak dari sebuah prodi yang maju akan menjadi magnet bagi masyarakat untuk menimba ilmu di dalamnya, bagaimana tidak ketika ada salah seorang alumninya telah menjadi pimpinan dalam sebuah instansi maka masyarakat akan bertanya dari perguruan tinggi mana pimpinan tersebut belajar.

Program studi yang maju menunjukkan bahwa visi yang sudah ditetapkan oleh perguruan tinggi tersebut telah dicapai, hal inilah yang menjadi barometer keberhasilan suatu program studi. Ketika prodi dikelola dengan baik maka kepercayaan masyarakat akan tumbuh dan dukungan akan terus bertambah. Satu ungkapan yang perlu direnungkan dalam mengelola prodi adalah "if good is not enough better is possible" Artinya melakukan yang terbaik secara terus menerus menjadi kuncinya.

\section{Strategi Pengembangan Prodi}

Sejak dari awal pendirian prodi prasyarat yang telah ditetapkan oleh pemerintah dalam hal ini Menteri Pendidikan Nasional sudah dipenuhi oleh semua prodi karena dokumen tersebut sudah harus ada ketika pengajuan pendiriannya, hanya saja penyebaran informasi tentang program-program yang telah ditetapkan oleh prodi tersebut tidak diketahui oleh masyarakat, bahkan tidak diketahui juga oleh civitas akademika sendiri seperti mahasiswa, pegawai kependidikan dan juga dosen oleh karena itu sering terjadi kurang mendapat dukungan dari semua pihak karena memang komunikasi dengan semua elemen di atas tidak dilakukan. Hal inilah yang disebut dengan sosialisasi ke dalam dan selanjutnya sosialisasi ke luar yang disebut dengan promosi.

Tujuan dari sosialisasi ke dalam adalah untuk diketahui oleh seluruh sivitas akademika yang ada agar supaya semua elemen yang ada ikut serta mendukung program yang sudah ditetapkan sehingga bisa dengan cepat tercapai visi yang dicanangkan. Sosialisasi ke luar yang dilakukan oleh banyak perguruan tinggi adalah dengan menyebarkan selebaran-selebaran yang 
392 | TAZKIR: Jurnal Penelitian Ilmu-ilmu Sosial dan Keislaman

Vol. 04 No. 2 Desember 2018

berbentuk brosur, atau menempelkan pengumuman di dinding-dinding sekolah dan ada juga yang membuat spanduk di jalan-jalan, langkah ini merupakan sebagian kecil dari langkah sosialisasi yang biasa dilakukan.

Dalam era digital ini menggunakan media internet melalui media sosial yang ada juga memiliki peran yang besar pula apalagi jiga menggunakan media informasi seperti Radio atau Televisi dan media yang terakhir ini hanya dilakukan oleh perguruan tinggi yang kuat saja secara finansial. Hal inilah yang dirasakan oleh Program Studi yang langka peminat kurang mensosialisasikan visi misi, tujuan dan target prodi, menguatkan proses pembelajaran, kepemimpinan, manajemen, jaminan kualitas, kualitas alumni, tenaga kependidikan dan dosen, meningkatkan penelitian, pelayanan kepada masyarakat dan kerjasama dengan berbagai-pihak. ${ }^{10}$

Penguatan elemen-elemen di atas menjadi syarat mutlak untuk memajukan lembaga perguruan tinggi, hal ini tentunya harus menjadi prioritas dalam menentukan kebijakan dan pengalokasian dana yang ada, sebab elemen di atas merupakan ruh/jiwa dari sebuah lembaga pendidikan khususnya perguruan tinggi. Hanya saja hal di atas kurang mendapatkan perhatian serius dari para pimpinan lembaga karena tidak instan kemajuan yang dirasakan dan tidak nampak di mata keelokan bangunan dan keluasan areal yang dimiliki.

Hasil penelitian pihak lain menjelaskan bahwa:1) Pemahaman stakeholder terhadap realitas kelangkaan peminat pada program studi langka peminat di PTAIN adalah prodi ini krisis input, ada pemahaman yang salah dari masyarakat tentang Prodi Aqidah dan Filsafat (AF), ketidakjelasan lapangan pekerjaan bagi lulusan Prodi AF; 2) Mutu proses pendidikan relatif memenuhi kepuasan pelanggan. Permasalahan mutu prodi Aqidah dan Filsafat (AF) terletak pada mutu input dan mutu outputnya; 3) Strategi peningkatan mutu pendidikan dititikberatkan pada peningkatan Relevancy dan Sustainability yang selama ini menjadi problem pokok pada prodi Aqidah. ${ }^{11}$

Penguatan elemen-elemen sebuah lembaga pendidikan dari tujuan dan target prodi, menguatkan proses pembelajaran, kepemimpinan, manajemen, jaminan kualitas, kualitas alumni, tenaga kependidikan dan dosen,

${ }^{10}$ Ashar, Strategi Pengembangan Program Studi Ahwalussyahsiyah Jurusan Syariah dan Ekonomi Islam STAIN Samarinda, Jurnal Fenomena Vol.6 No.2 2014

${ }^{11}$ Fetty Ernawati dan Djam'an Satori, Strategi Peningkatan Mutu Pendidikan Pada Program Studi Langka Peminat dI PTAIN, Jurnal Administrasi Pendidikan Vol.XV No.1 April 2012 hlm.12 
meningkatkan penelitian, pelayanan kepada masyarakat, kerjasama dengan banyak pihak dan sosialisasi yang intens serta meluas adalah strategi yang dapat diandalkan bagi memperbanyak animo masyarakat untuk memilih prodi yang ditawarkan.

\section{Upaya Prodi-Prodi Banyak Peminat}

Program Studi Manajemen Dakwah dan Program Studi Pengembangan Masyarakat Islam Universitas Islam Negeri (UIN) Suska Pekanbaru merupakan dua prodi yang masuk dalam prodi yang banyak peminat, Menurut Dekan Fakultas Dakwah dan Komunikasi UIN Suska Dr. Nurdin, MA dalam acara silaturrahim peneliti di Fakultasnya menjelaskan bahwa alih status UIN Suska terjadi pada tahun 2005 sedangkan Prodi Manejemen Dakwah berdiri pada tahun 2002, alih status inilah salah satu faktor yang mendongkrak kemajuan semua prodi. ${ }^{12}$

Saat ini Prodi Manejemen Dakwah memiliki 900 orang mahasiswa, Prodi Pengembangan Masyarakat Islam memiliki 450 orang Mahasiswa, Prodi Bimbingan dan Konseling Islam memiliki 700 orang mahasiswa dan Prodi Komunikasi mahasiswanya sebanyak 2635 orang. Mahasiswa baru yang masuk pada Tahun Akademik 2018-2019 sebagai berikut; Prodi MD 260 orang, Prodi PMI 147 orang, Prodi BKI 170 orang dan Prodi Ilmu Komunikasi sebanyak 406 orang. Jumlah peminat yang cukup signifikan:

1. Program Studi yang berada di bawah koordinasi Diknas/Dikti (Widermainded Program) seperti Prodi Ilmu Komunikasi.

2. Sosialisasi yang cukup gencar dilakukan dan terus menerus, baik sosialisasi administrasi seperti menyebarkan brosur, spanduk, baliho dan lain-lain.

3. Sosialisasi melalui media, media portal yang ada di internet diisi oleh mahasiswa FDK, semua kegiatan mahasiswa FDK di-upload melalui jejaring tersebut.

4. Streaming TV, kegiatan mahasiswa FDK di-upload di youtube dan dapat ditonton oleh orang banyak

5. Semua media yang ada di Riau bisa dipastikan ada alumni FDK di dalamnya.

${ }^{12}$ Nurdin, (Dekan Fakultas Dakwah dan Komunikasi UIN Suska Riau) dalam Acara Silaturrahim di FDK UIN Suska Pekanbaru, 13-14 Agustus 2018 
394 | TAZKIR: Jurnal Penelitian Ilmu-ilmu Sosial dan Keislaman

Vol. 04 No. 2 Desember 2018

6. Bangunan fisik yang indah bantuan dari IDB juga mendukung indahnya kampus sehingga masyarakat tertarik dengan penampilan tersebut.

7. Biaya kuliah di FDK yang paling murah, sehingga mendorong masyarakat kampung memilih masuk ke FDK.

8. Pendekatan kepada Pemda dari tingkat Provensi sampai kepada Daerah Kabupaten dan Kota yang akan menerima alumninya sebagai pegawai nantinya.

9. Melakukan kerjasama dengan berbagai pihak untuk menjadikan tempat mahasiswa magang.

10. Proses yang mengarah kepada kemajuan tidak singkat, akan memerlukan waktu yang cukup lama.

Selanjutnya Ketua Jurusan Manajemen Dakwah, Dr. Imron Rosidi, MA. menambahkan bahwa untuk menjadikan prodi itu banyak peminat adalah melakukan hal-hal berikut ini: ${ }^{13}$

1. Meningkatkan Akreditasi prodi dapat mendongkrak minat masyarakat untuk masuk ke prodi tersebut, dan Prodi Manajemen Dakwah FDK UIN Suska sudah memperoleh akreditasi A.

2. Sosialisasi internal dengan melakukan berbagai kegiatan akademik dan non akademik di dalam kampus dan di luar kampus dan diupload ke media sosial.

3. Membuka konsentrasi-konsentrasi baru dalam jurusan tersebut, seperti konsentrasi travel haji dan umrah, konsentrasi pengelola zakat, konsentrasi pengelola dakwah dan wakaf dan lain-lain.

4. Para dosen dan mahasiswa hendaknya bergabung di dalam asosiasi sosial dan keagamaan.

5. Pengaktifan laboratorium. FDK UIN Suska memiliki tujuh laboratorium; labor dakwah dan labor masyarakat seperti desa binaan.

6. Mendatangkan Profesor/pakar untuk memberikan kuliah tentang peta sosial masyarakat sehingga tebuka peluang untuk mengembangkan potensi dan kompetensi yang dimiliki oleh dosen maupun mahasiswa.

${ }^{13}$ Acara Silaturrahmi di FDK UIN Suska, 13-14 Agustus 2018 


\section{HASIL PENELITIAN DAN PEMBAHASAN}

Hasil penelitian yang dilakukan oleh Sholeh Fikri dari bulan November 2017 hingga Agustus 2018 yang berjudul “Upaya peningkatan prodi langka peminat di IAIN Padangsidimpuan Studi kasus Prodi Manajemen Dakwah dan Prodi Pengembangan Masyarakat Islam" mendapatkan bahwa pendirian Prodi Manajemen Dakwah dan Prodi Pengembangan Masyarakat Islam belum diketahui oleh stakeholder yang ada, baik lembaga pemerintah seperti Kementrian Agama Kota Padangsidimpuan dan Kabupaten Tapanuli Selatan, Lembaga Pemasyarakatan Kelas IIB Kota Padangsidimpuan, Dinas Pemberdayaan Masyarakat Desa, Dinas Kotaku, Bazda Kota Padangsidimpuan, lembaga- lembaga pendidikan baik yang ada di dalam Kota Padangsidimpuan maupun lembaga pendidikan yang ada di kabupaten Tapanuli Selatan, Kabupaten Mandailing Natal, Kabupaten Padanglawas Utara (Paluta).

Kejadian ini terjadi karena dalam pendiriannya kurang banyak melibatkan calon pengguna, sumber calon mahasiswa baik sekolah maupun pesantren yang ada di sekitar kota Padangsidimpuan dan Tabagsel. Selanjutnya sosialisasi akan keberadaan dua prodi ini baik melalui selebaran-selebaran maupun melalui media masa cetak maupun elektronik belum optimal dipergunakan sehingga informasi belum sampai secara merata, selain daripada alumni kedua prodi ini masih sedikit atau sampai penelitian ini dilakukan baru ada tiga orang yang baru menyelesaikan studinya. Dari Prodi Manajemen Dakwah ada dua orang alumni, Muhammad Arifin dan Siti Khalijah, sedangkan dari Prodi Pengembangan Masyarakat Islam ada tiga orang yaitu: Nur Harisah Hasibuan, Ika Saputri dan Iska Amelia Harahap.

Upaya yang telah dilakukan oleh pimpinan FDIK sudah cukup banyak dari pelengkapan dokumen yang dibutuhkan dalam pengembangan fakultas dan prodi- prodi yang ada di bawahnya, kegiatan-kegiatan untuk pengembangan prodi juga sudah dilakukan secara maksimal, terbukti dengan terakreditasinya empat prodi yang ada di FDIK, dua prodi sudah terakreditasi B dan dua lagi masih terakreditasi C. Akreditasi merupakan standar kemajuan sebuah prodi. Masih banyak lagi sebetulnya kegiatan yang perlu dilakukan untuk 
396 | TAZKIR: Jurnal Penelitian Ilmu-ilmu Sosial dan Keislaman

Vol. 04 No. 2 Desember 2018

kemajuan FDIK secara keseluruhan seperti yang dikatakan oleh Dekan pertama, Fauziah Nasution, M.Ag: 1). Mengajak pemerintah asal mahasiswa untuk memberikan beasiswanya kepada rakyatnya yang sedang kuliah. 2). Promosi kurang maksimal, belum proporsional dan belum profesional. 3). Kerjasama dengan stakeholder lebih intens lagi. 4). Diharapkan stakeholder dapat memberikan beasiswa kepada mahasiswa yang terkait dengan instansinya. 5). Institut belum berpihak kepada kepada prodi yang langka peminat, bahkan masing-masing fakultas hanya berfikir untuk fakultasnya. 6). Akreditasi harus mendapatkan nilai yang optimal karena akan berpengaruh menarik minat masyarakat untuk masuk. 7). PMI memang kurang gencar promosinya. 8). Pelibatan mahasiswa dalam berbagai kegiatan bersama dengan stakeholder. 9). Memperbanyak MOU dengan berbagai pihak, dosen-dosen yang punya relasi dengan instansi-instansi dan memiliki posisi dalam instansi tersebut bisa memiliki kepemimpinan publik dan bisa menjalin kerjasama sehingga dapat melibatkan mahasiswa dalam berbagai kegiatan.

Sedangkan menurut Ka. Prodi PMI periode 2014-2017 Dra. Hj. Replita, M.Si., hal-hal yang belum terlaksana adalah: 1). Memperbanyak informasi tentang lowongan kerja bagi alumni PMI. 2). Memperbanyak peraktek ke masyarakat. 3). Melakukan pendekatan kepada kepala-kepala sekolah. 4). Promosi melalui media sosial yang dilakukan oleh mahasiswa perlu diperbanyak lagi.

Ka. Prodi Manajemen Dakwah periode 2014-2017 Ali Amran, M.Si. menjelaskan bahwa ada beberapa kegiatan yang belum dilakukan, diantaranya: 1) Memperbanyak kegiatan kemahasiswaan di tengahtengah masyarakat. 2). Memperbanyak study tour untuk membuka mindset mahasiswa dan sekaligus dikenal oleh masyarakat banyak 3). Mengikutkan mahasiswa dalam kegiatan- kegiatan ilmiah yang bertaraf nasional.

Uraian yang diutarakan oleh pimpinan fakultas maupun prodi yang menakodai langsung prodi yang langka peminat tersebut mengakui bahwa masih banyak kegiatan-kegiatan yang belum terlaksana kendatipun mereka sudah berusaha maksimal untuk melakukannya, hal itu terjadi disebabkan oleh berbagai hal baik internal maupun eksternal dan bisa juga terjadi karena keterbatasan waktu dan tenaga yang ada. 


\section{KESIMPULAN}

Kajian tentang upaya meningkatkan program studi yang langka peminat tidak akan selesai sampai pada kajian di atas saja karena tuntutan kemajuan zaman juga terus berkembang sehingga kemajuan suatu prodi dituntut untuk dapat mengimbanginya. Prodi yang sudah banyak peminatnya dituntut untuk memperbaiki kualitas agar dapat melahirkan alumni yang berkualitas dan prodi yang langka peminat juga dituntut sama meningkatkan kualitas para mahasiswanya walaupun sedikit sehingga bisa menjadi mercusuar bagi kemajuan prodi yang telah melahirkannya.

Kemajuan akan dicapai oleh prodi yang berbasis Islam jika senantiasa mengedepankan tatakelola manajemen dan administrasi yang baik, proses pendidikan dan pengajaran yang berkualitas dan didukung oleh jaringan yang luas untuk menampung lulusan-lulusan yang ada. 
398 | TAZKIR: Jurnal Penelitian Ilmu-ilmu Sosial dan Keislaman

Vol. 04 No. 2 Desember 2018

\section{DAFTAR BACAAN}

Arief Furchan. Transformasi Pendidikan Islam di Indonesia Yogyakarta: Gama Media, 2004

Ashar, Strategi Pengembangan Program Studi Ahwalussyahsiyah Jurusan Syariah dan Ekonomi Islam STAIN Samarinda, Jurnal Fenomena Vol.6 No.2 2014

Azyumardi Azra. IAIN di Tengah Paradigma Baru Perguruan Tinggi. Tersedia http://www.diktis.net/artikel/azyu01.asp, diakses 05 Maret 2018.

Fakultas Dakwah dan Ilmu Komunikasi, Renstra FDIK 2014-2022

Fetty Ernawati dan Djam'an Satori, Strategi Peningkatan Mutu Pendidikan Pada Program Studi Langka Peminat DI PTAIN, Jurnal Administrasi Pendidikan Vol.XV No.1 April 2012

Nunun Tri Widarwati, Pengelolaan Program Studi, Jurnal Widyatama, No.2 / Volume 21 / 2012

Qomar Mujamil. Manajemen Pendidikan Islam: Strategi Baru Pengelolaan Lembaga Pendidikan Islam, Jakarta: Erlangga, 2007

Serian Wijatno, Pengelolaan Perguruan Tinggi Secara Efisien, Efektif, dan Ekonomis: Untuk Meningkatkan Mutu Penyelenggaraan Pendidikan Mutu Lulusan, Jakarta: Salemba Empat, 2009

Sistem Informasi Akademik (SIAKAD) Fakultas Dakwah dan Ilmu Komunikasi IAIN Padangsidimpuan, diakses 20 Desember 2017. 